\title{
Analisis Kesalahan Penulisan Algoritma Pemrograman Delphi Pada Mahasiswa Jurusan Pendidikan Matematika UIN Mataram
}

\author{
Rina Mariana ${ }^{1}$, M. Fauzi ${ }^{2}$ \\ ${ }^{1}$ Tadris Matematika, Universitas Islam Negeri Mataram, rinamariani8@gmail.com, \\ 2STMIK Bumigora Mataram, muh.fauzi@gmail.com
}

\section{INFO ARTIKEL}

Riwayat Artikel:

Diterima: 08-07-2018

Disetujui: 20-10-2018

\section{Kata Kunci:}

Algoritma

Pemrograman

Delphi

\begin{abstract}
ABSTRAK
Abstrak: Penelitian ini merupakan penelitian kualitatif dengan objek penelitian adalah mahasiswa Jurusan Pendidikan Matematika UIN Mataram yang bertujuan untuk menganalisis bentuk kesalahan yang sering dilakukan oleh mahasiswa dalam menyusun scribs komputasi pada praktikum Delphi. Tim peneliti menggunakan purposive sampling, dengan sampel penelitian berjumlah 139 mahasiswa. Metode pengumpulan data terdiri dari metode observasi, interview, dan dokumentasi. Kemudian data yang terkumpul dianalisa menggunakan analisa data model Spradley yang terdiri dari: Analisis Doamin, Taksonomi, Komponensial, dan Tema. Hasil penelitian menunjukkan bahwa berbagai macam bentuk kesalahan yang dilakukan oleh mahasiswa yakni (1) tidak mendeklarasikan (mendefinisikan) variabel yang digunakan dalam rumus atau instruksi; (2) Kesalahan penulisan pada tanda baca, seperti tanda baca titik , koma, titik dua, titik koma, tanda kurung, dan sama dengan; (3) kesalahan penulisan pada huruf khususnya pada konversi data; dan (4) kesalahan dalam mengkhiri instruksi pemrograman.
\end{abstract}

\begin{abstract}
This research is a qualitative research with the object of research is the Mathematics Education Department of UIN Mataram students whose purpose is to analyze the forms of errors that are often carried out by students in compiling computational scribs in the Delphi practicum. The research team used purposive sampling, with a sample of 139 students. The method of data collection consists of methods of observation, interviews, and documentation. Then the collected data was analyzed using Spradley model data analysis which consisted of: Domain Analysis, Taxonomy, Componential, and Themes. The results showed that various forms of errors made by students namely (1) did not declare (define) variables used in formulas or instructions; (2) Writing errors in punctuation marks, such as punctuation marks, commas, colons, semicolons, parentheses, and are equal to; (3) writing errors in letters especially in data conversion; and (4) errors in terminating programming instructions.
\end{abstract}

\section{A. LATAR BELAKANG}

Penelitian ini berawal dari permasalahan yang ada di kalangan mahasiswa yang mengikuti kuliah matematika komputasi. Matematika komputasi ini diaplikasikan dalam bentuk pembelajaran berbagai program komputer. Adapun program komputer tersebut terdiri dari program Delphi, Mathlab, Macromedia Flash, SPSS, C++, Maple, QS, dan Iteman. Program-program ini diberikan sesuai dengan jenjang (semester), Asisten Pembina, dan Pembina masing-masing program. Delapan program komputer tersebut memiliki ciri khas tersendiri. Sehingga tingkat penguasaan konsep, keterampilan dan motivasi mahasiswa terhadap program tersebut juga berbeda.

Menurut hasil observasi dan wawancara kepada para Asisten Pembina program dan praktikan, diperoleh data bahwa jika dipandang dari segi kesulitan penulisan dan teknik algoritma pemrograman dari masing-masing program ternyata Delphi merupakan program yang sifatnya simpel tapi membutuhkan ketelitian dalam penulisan algoritma pemrogramannya. Di samping itu juga, yang menjadi permasalahan adalah keadaan mahasiswa yang dominan masih awam akan program-program komputer. Sehingga pada saat praktikum, mereka masih kaku untuk mengembangkan diri dalam 
menguasai program komputer. Sementara sebagaimana yang diketahui bersama bahwa matematika merupakan ilmu berbasis perhitungan mulai dari permasalahan sederhana (analitis) sampai permasalahan kompleks (numerik). Sehingga peran dari beberapa program komputer tersebut benarbenar dibutuhkan demi ketercapaian penguasaan teori, konsep, dan aplikasi matematika secara keseluruhan.

Menurut hasil observasi tersebut dijelaskan juga bahwa setiap praktikan (mahasiswa) sering melakukan kesalahan dalam penulisan algoritma pemrograman Delphi. Mereka mengatakan bahwa setiap pertemuan (pembuatan aplikasi program) pasti ada kesalahan penulisan yang terjadi ketika program dalam posisi di-run atau dijalankan. Kesalahan tersebut bervariasi namun tidak pernah keluar dari algoritma pemrogramannya. Sehingga terkadang kesalahan penulisan tersebut membuat para praktikan mengeluh dan enggan melaksanakan praktikum. Tentu fenomena ini akan melahirkan masalah baru lagi yakni tingkat keberhasilan pelaksanaan perkuliahan matematika komputasi untuk program Delphi masih tergolong rendah karena dari segi penguasaan konsep hanya mencapai rata-rata 66,33, dari segi keterampilan hanya mencapai rata-rata 67,88 , dan dari segi motivasi untuk belajar bahasa pemrograman Delphi hanya mencapai rata-rata 67,28, maka secara keseluruhan tingkat keberhasilan pelaksanaan praktikum program delphi hanya mencapai rata-rata 67,17. Sehingga bisa dikatakan bahwa penguasaan konsep, keterampilan, dan motivasi mahasiswa untuk belajar bahasa pemrograman Delphi masih tergolong rendah. Nilai ini masih jauh dari harapan untuk menciptakan matematikawan yang memiliki kompetensi matematika berbasis komputer.

Setiap masalah memiliki solusi. Namun sebelum menemukan solusi, maka harus disusun algoritma penyelesaian masalah mulai dari diagnosis "mengapa" dan "darimana" masalah itu datang, pemilihan metode penyelesaian, pelaksanaan, sampai penarikan kesimpulan (solusi). Berdasarkan apa yang dikemukakan di atas, maka peneliti mengambil judul dalam penelitian ini adalah "Analisis Kesalahan Penulisan Algoritma Pemrograman Delphi Pada Mahasiswa Jurusan Pendidikan Matematika UIN Mataram"

\section{B. METODE PENELITIAN}

\section{Pendekatan Penelitian}

Menjadi ciri khas penelitian kualitatif adalah bersifat deskriptif, peneliti langsung sebagai instrumen penelitian, menggunakan triangulasi dalam pemeriksaan kebenaran data, sampel dipilih secara purposif dan menggunakan audit trail (Hadi, 1998). Jadi, penelitian ini merupakan penelitian kualitatif untuk mendeskriptisikan bentuk-bentuk kesalahan yang dilakukan oleh mahasiswa dalam membangun scribs komputasi pada praktikum Delphi.

\section{Instrumen dan Kehadiran Peneliti}

Pada prinsipnya, meneliti adalah melakukan pengukuran terhadap fenomena sosial maupun alam, maka perlu ada alat ukur yang baik. Karena alat ukur tersebut akan berpengaruh pada kualitas hasil pengukuran. Terdapat dua hal utama yang mempengaruhi kualitas hasil penelitian yaitu, kualitas instrumen penelitian dan kualitas pengumpulan data. Dalam penelitian kualitatif, yang menjadi instrumen atau alat penelitian adalah peneliti itu sendiri (Sugiyono, 2010). Instrumen kunci dalam penelitian kualitatif adalah peneliti itu sendiri. Dengan kedudukan peneliti sebagai instrumen penelitian maka kehadiran peneliti dalam proses pengumpulan data sangat diharapkan secara maksimal agar data yang terkumpul memiliki kualitas validitas yang tinggi.

\section{Objek Penelitian}

Objek penelitian ini adalah seluruh mahasiswa semester I Jurusan Pendidikan Matematika UIN Mataram yang terdiri dari 33 orang kelas A, 36 orang kelas B, 34 orang kelas C, dan 36 orang kelas D

\section{Teknik Pengumpulan Data}

Teknik pengumpulan data yaitu metode atau cara-cara yang dapat digunakan oleh peneliti untuk mengumpulkan data. Teknik atau alat pengumpulan data pada penelitian kualitatif, yaitu wawancara, riset partisipatif, pengamatan, studi pustaka, dan sumber data berasal dari dokumen, koran, majalah, jurnal ilmiah, dan lain-lain (Afifuddin, ). Sedangkan dalam penelitian ini hanya digunakan metode observasi, interview, dan dokumentasi saja.

\section{Teknik Analisa Data}

Analsis data kualitatif menurut Bogdan dan Biklen 1982) dalam Moleong adalah upaya yang dilakukan dengan jalan bekerja dengan data, mengorganisasikan data, memilih-memilahnya menjadi satuan yang dapat dikelola, mensintesiskannya, mencari dan menemukan pola, menemukan apa yang penting dan apa yang dipelajari, dan memutuskan apa yang dapat diceritakan kepada orang lain. Dalam penelitian ini, peneliti menggunakan model Spradley dalam melakukan analisis data, yang terdiri dari (1) Analisis Domain (Domain Analysis), dari teknik analisis ini peneliti akan menemukan dan mereduksi data kedalam berbagai kategori yang menjadi kesalahan penulisan algoritma pemrograman Delphi; (2) Analisis Taksonomi (Taxonomic Analysis), hasil analisis taksonomi dapat disajikan dalam bentuk 
diagram kotak (box diagram), diagram garis dan simpul (lines and node diagram), dan outline; (3) Analisis Komponensial (Componential Analysis), analisis ini dilakukan melalui observasi dan wawancara terseleksi dengan pertanyaan yang mengkontraskan; dan (4) Analisis Tema (Discovering Cultural Theme), analisis terakhir adalah analisis tema. Dimana peneliti mencari hubungan diantara domain, dan bagaimana hubungan dengan keseluruhan, dan selanjutnya dinyatakan ke dalam tema/judul penelitian.

\section{HASIL DAN PEMBAHASAN}

\section{Bentuk Kesalahan}

Setelah dilakukan beberapa uji coba kemampuan mahasiswa dalam mengembangkan program aplikasi yang diawali dengan membangun scribs melalui editor, maka dapat ditemukan beberapa kesalahan penulisan scribs tersebut. Kesalahan penulisan algoritma pemrograman selalu ditandai dengan warna merah di tempat salah penulisan ketika program dalam posisi dieksekusi (run) melalui tombol $\triangle$ yang ada pada Speed Bar atau F9 yang ada di keyboard. Berdasarkan hasil analisa data maka diperoleh data tentang berbagai bentuk kesalahan penulisan algoritma pemrograman Delphi sebagai berikut:

a. Tidak mendeklarasikan (mendefinisikan) variabel yang digunakan dalam rumus atau instruksi. Pada gambar di bawah ini merupakan contoh kesalahan penulisan karena tidak menulis kata var (variabel) untuk mendefinisikan variabel yang akan digunakan.

b. Kesalahan penulisan pada tanda baca, seperti tanda baca titik , koma, titik dua, titik koma, tanda kurung, dan sama dengan. [ . , : ; ( ) = ]. Contohnya:

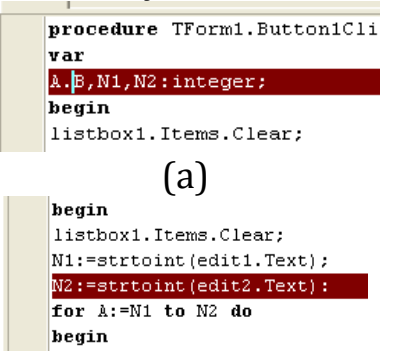

(c)

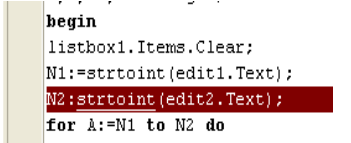

(b)

N2: =strtoint (edit 2. Text) for $\mathrm{A}:=\mathrm{N} 1$ to $\mathrm{N} 2$ do begin $B:=\operatorname{sqr}[\mathrm{L}]$ listbox1. Items. Add (inttostr! (d)
Gambar 2. Kesalahan penulisan tanda titik, titik dua, sama dengan dan kurung

Pada gambar 2(a) di atas terlihat kesalahan penulisan pada tanda titik yang sebenarnya adalah tanda koma, pada gambar 2(b) kesalahan penulisan karena tidak menaruh tanda sama untuk mendefinisikan jenis tipe data dan letak instruksi akan dieksekusi, pada gambar 2(c) kesalahan penulisan pada tanda titik dua yang sebenarnya adalah tanda titik koma, dan pada gambar 2(d) kesalahan penulisan pada kurung siku [ ] yang sebenarnya adalah kurung biasa ().

c. Kesalahan penulisan pada huruf, baik pada konversi data yang terdiri dari (a) Strtoint, mengubah tipe data string ke integer, (b) Inttostr, mengubah tipe data integer ke string, (c) Timetostr, mengubah tipe data time ke dalam bentuk string, (d) Strtofloat, mengubah tipe data string ke dalam bentuk real, dan (e) Floattostr, mengubah tipe data real ke dalam bentuk string, maupun pada penulisan huruf yang lainnya. Contohnya:

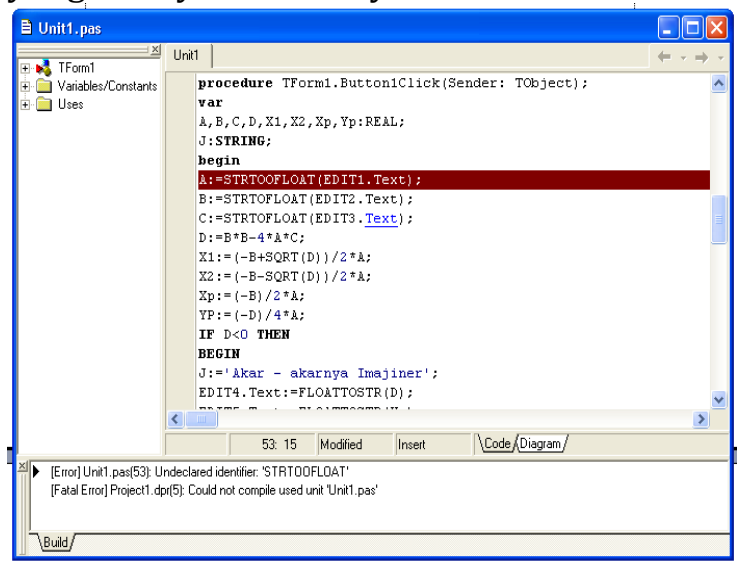

Gambar 3. Kesalahan penulisan pada huruf

Pada Gambar 3 di atas terlihat kesalahan penulisan pada tanda huruf yakni kata strtoofloat yang sebenarnya adalah kata strtofloat.

d. Kesalahan dalam mengkhiri instruksi pemrograman. Contohnya:

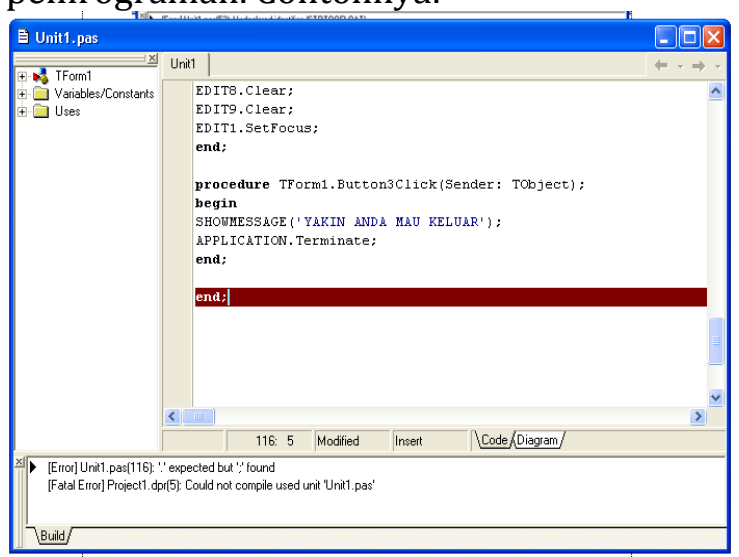

Gambar 4. Kesalahan penulisan pada end

Pada Gambar 4 di atas terlihat kesalahan penulisan dalam mengkhiri instruksi pemrograman yakni kata end; yang sebenarnya adalah kata end. Dari berbagai bentuk kesalahan penulisan algoritma pemrograman Delphi tersebut maka terdapat sepuluh (10) bentuk kesalahan yakni: (1) Tanda titik, (2) Tanda koma, (3) Tanda titik dua, (4) Tanda titik koma, (5) 
Tanda kurung, (6) Tanda sama dengan, (7) Huruf/kata, (8) Var/begin, (9) Operasi, dan (10) End.

Dari hasil observasi diperoleh data tentang frekuensi kesalahan penulisan algoritma pemrograman Delphi seperti terlihat pada diagram berikut ini.

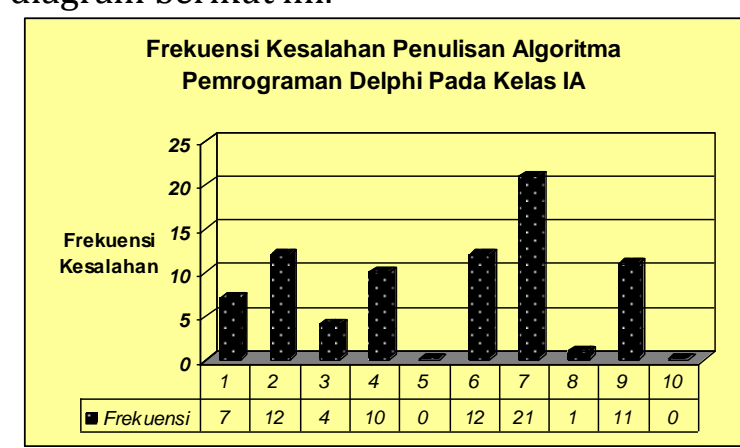

(a)

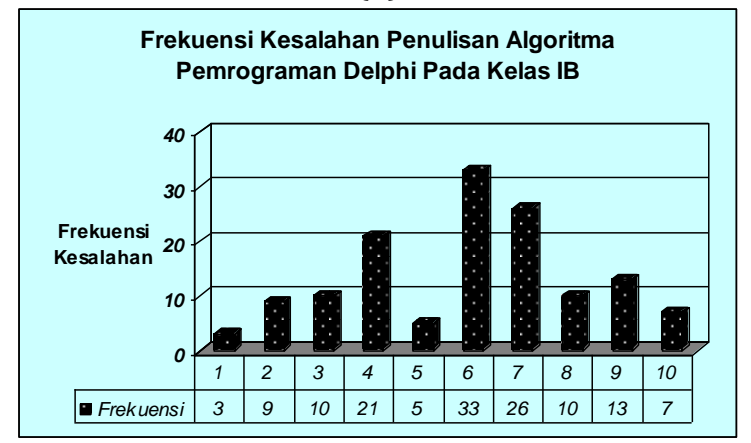

(b)

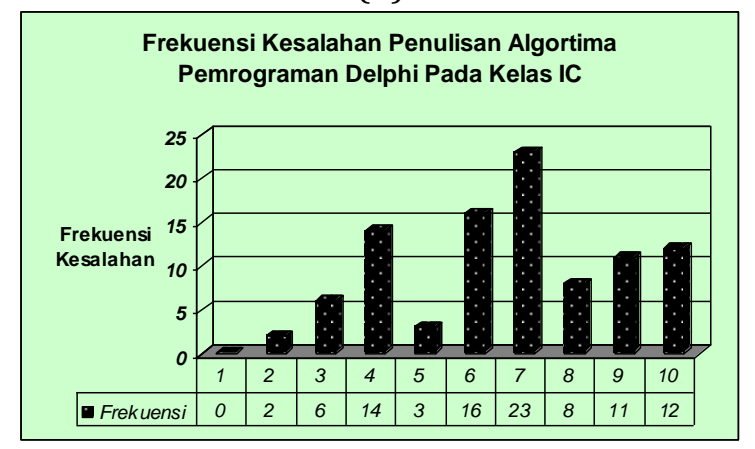

(c)

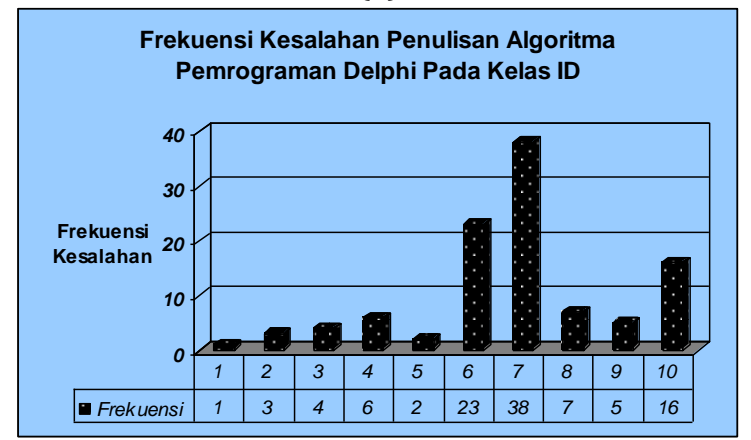

(d)

Gambar 5. (a,b,c,d) Frekuensi Kesalahan Penulisan Algortima Pemrograman Delphi Pada Masing-masing Kelas
Bentuk dan Frekuensi Kesalahan Penulisan Algoritma Pemrograman Delphi

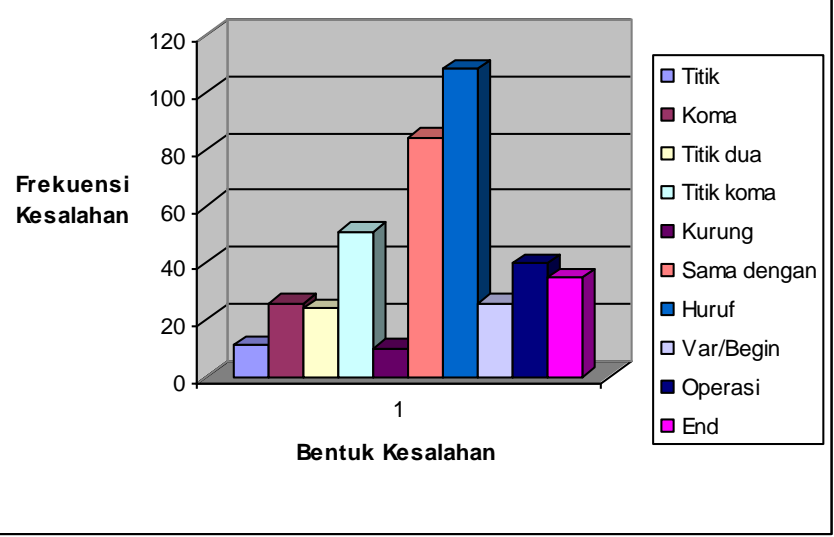

Gambar 6. Bentuk dan Frekuensi K_ualahan Penulisan

Algoritma Pemrograman Delphi

\section{Faktor-faktor yang Mempengaruhi Kesalahan} Penulisan Algoritma Pemrograman Delphi

Berdasarkan hasil analisa data selama penelitian, peneliti menemukan beberapa faktor yang mempengaruhi kesalahan penulisan algoritma pemrograman Delphi yang terbagi dalam dua (2) kategori yakni faktor internal dan faktor eksternal.

a. Faktor-faktor Internal

Adapun faktor internal yang mempengaruhi kesalahan penulisan algoritma pemrograman Delphi yakni sebagai berikut:

1) Kemampuan komputerisasi mahasiswa masih kurang. Faktor ini merupakan salah satu indikator yang mempengaruhi kesalahan penulisan algoritma pemrograman Delphi. Semakin tinggi pemahaman atau pengetahuan mahasiswa akan komputer maka semakin sedikit kemungkinan terjadinya kesalahan penulisan algoritma pemrograman Delphi. Karena tinggi rendahnya pemahaman atau pengetahuan terhadap komputer berpengaruh pada kemahiran mahasiswa dalam mengetik atau menulis algoritma pemrograman (sintaksis) di komponen Code Explorer atau Code Editor pada program Delphi. Berdasarkan hasil analisa data, diperoleh data bahwa rata-rata mahasiswa jurusan pendidikan matematika semester I memahami komputer atau bisa mengetik. Namun tingkat kemahiran mahasiswa dalam mengetik yang berbeda. Hal ini terjadi karena waktu mengenal komputer masing-masing mahasiswa berbeda sesuai dengan tabel berikut ini. 
Tabel 1. Perbedaan Waktu Mengenal Komputer

\begin{tabular}{ccc}
\hline No & Jenjang & Jumlah \\
\hline 1 & SD & $1,39 \%$ \\
\hline 2 & SMP & $40,3 \%$ \\
\hline 3 & SMA & $45,83 \%$ \\
\hline 4 & PT & $13 \%$ \\
\hline & Jumlah & $100 \%$ \\
\hline
\end{tabular}

2) Kurangnya ketelitian dalam menulis algoritma pemrograman Delphi. Ketelitian merupakan salah satu sikap yang harus dimiliki oleh seorang programer untuk menghindari kesalahan baik pada prosedur maupun penulisan algoritma pemrograman. Hasil observasi dan interview menunjukkan bahwa kesalahan penulisan algoritma pemrograman Delphi juga dipengaruhi oleh kurangnnya ketelitian mahasiswa dalam menulis algoritma pemrograman Delphi.

3) Minimnya pemahaman terhadap algoritma pemrograman Delphi. Pemahaman terhadap algoritma pemrograman merupakan faktor yang sangat penting untuk menghindari kesalahan penulisan algoritma pemrograman. Minimnya pemahaman terhadap algoritma pemrograman Delphi tersebut disebabkan oleh beberapa hal sebagai berikut:

a) Mahasiswa tidak mengulangi pelajaran yang telah diberikan/dipelajari. Dengan mengulangi berarti mahasiswa berupaya untuk memperlancar atau menguasai secara penuh terhadap materi yang telah diperoleh.

b) Jadwal perkuliahan matematika komputasi belum teratur dan efektif. Jadwal praktikum berorientasi pada waktu belajar mahasiswa dalam mempelajari program Delphi secara penuh.

c) Kurangnya sugesti tentang maksud algoritma dari asisten pembina ketika praktikum berlangsung.

d) Tidak ada rasa iri atau semangat untuk berkompetensi dalam diri mahasiswa.

4) Mayoritas mahasiswa belum mengetahui tujuan pembelajaran program Delphi. Tujuan pembelajaran merupakan tolak ukur untuk membangkitkan semangat dan motivasi seseorang untuk belajar. Semakin tinggi pengetahuan mahasiswa akan tujuan pembelajaran khususnya manfaat dari program Delphi maka akan semakin tinggi minat dan motivasi mahasiswa untuk belajar program Delphi. Kurangnya pengetahuan akan tujuan pembelajaran program Delphi disebabkan beberapa hal sebagai berikut: a) Rendahnya tingkat kesadaran akan pentingnya belajar program Delphi yang merupakan aplikasi dari teori dan konsep matematika.

b) Adanya asumsi bahwa matematika komputasi tidak termasuk mata kuliah.

c) Disebabkan kesibukan, seperti kegiatan berorganisasi atau aktivitas perkuliahan.

b. Faktor-faktor Eksternal

Adapun faktor-faktor eksternal yang mempengaruhi kesalahan penulisan algoritma pemrograman Delphi yakni sebagai berikut:

1) Rendahnya tingkat profesionalisme asisten pembina. Profesionalisme asisten pembina merupakan indikator penting bagi kelancaran proses perkuliahan matematika komputasi. Karena profesionalisme berpengaruh pada metode dan strategi yang digunakan, serta penguasaan konsep tentang algoritma pemrograman Delphi.

2) Sarana atau fasilitas kurang memadai (lengkap). Fasilitas praktikum merupakan indikator paling urgensi dalam meningkatkan kualitas hasil perkuliahan matematika komputasi.

3) Mutu isi modul atau panduan praktikum masih kurang kompetensi. Kualitas isi modul/panduan praktikum memiliki peran penting dalam menentukan output dari praktikum itu sendiri. Karena kualitas isi yang baik dan interaktif akan mampu menanamkan konsep-konsep bahasa pemrograman khususnya program Delphi kepada mahasiswa. Sehingga akan lahir ide-ide baru dalam mengembangkan konsep yang sudah ada. Tentu hal ini akan berpengaruh pada kualitas hasil praktikum terutama pada mahasiswa sendiri sebagai objek praktikum. Namun yang terlihat di laboratorium matematika UIN Mataram, kualitas isi modul masih tergolong rendah dan kurang interaktif terutama modul praktikum program Delphi. Hal ini terbukti dari output praktikum yang masih tergolong rendah akan pemahaman tentang konsep-konsep bahasa pemrograman.

4) Materi perkuliahan matematika komputasi untuk program Delphi tidak memiliki korelasi dengan materi perkuliahan matematika yang lainnya. Menurut hasil dokumentasi diperoleh data bahwa isi/materi yang ada dalam buku panduan praktikum Delphi tidak memiliki korelasi dengan materi perkuliahan matematika lainnya. Hal ini mengakibatkan mahasiswa/praktikan tidak memiliki motivasi dan kreativitas yang tinggi untuk 
belajar program delphi. Di samping itu, karena tidak memiliki hubungan antar mata kuliah maka mahasiswa merasa bahwa aplikasi program yang dibuat tidak memiliki manfaat dan pengaruh bagi pengembangan kemampuan matematika mahasiswa khususnya transferisasi teori dan konsep matematika menjadi algoritma pemrograman khususnya program Delphi.

\section{Upaya-upaya yang Dilakukan untuk Mengatasi Kesalahan Penulisan Algoritma Pemrograman Delphi}

Setiap permasalahan pasti memiliki solusi. Maka dari berbagai bentuk kesalahan penulisan algoritma pemrograman peneliti mencari sebab dari kesalahan tersebut yang terklasifikasi dalam faktor-faktor yang mempengaruhi kesalahan penulisan algoritma pemrograman delphi. Kemudian terakhir, peneliti melakukan observasi dan interview kembali untuk menemukan solusi atau upaya-upaya yang harus dilakukan untuk mengatasi kesalahan penulisan algortima pemrograman delphi secara khusus dan peningktan kualitas hasil perkuliahan matematika komputasi secara umum.

Menurut hasil observasi dan interview diperoleh beberapa upaya sebagai berikut:

a. Pihak Jurusan

Pihak jurusan sebagai penyelenggara memiliki peran penting dalam mengatasi permasalahan yang ada di laboratorium khususnya perkuliahan matematika komputasi yang merupakan ciri khas bagi jurusan pendidikan matematika UIN Mataram. Maka dalam hal ini sebagai penyelenggara, pihak jurusan perlu melakukan tindakan sebagai berikut:

1) Perlu adanya perbaikan dan peningkatan pada sarana perkuliahan matematika komputasi. Sarana seperti komputer memiliki peran penting karena tanpa komputer perkuliahan matematika komputasi tidak dapat di lakukan. Namun pada kenyataan yang kita lihat bahwa keadaan komputer di laboratorium sangat memperihatinkan. Dimana kondisi komputer jauh lebih sedikit jika dibandingkan dengan jumlah mahasiswa yakni 8 : 40. Setiap kali praktikum mahasiswa rata-rata sebanyak 40 perkelas harus duduk di depan komputer yang hanya terdiri dari 8 unit. Maka dari itu, perlu ada tindakan dari jurusan selaku penanggung jawab serta penyelenggara perkuliahan matematika komputasi untuk memperbaiki dan meningkatkan keadaan sarana perkuliahan khususnya penambahan jumlah komputer.
2) Dikaitkan dengan mata kuliah. Asumsi bahwa matematika komputasi tidak memiliki kaitan dan pengaruh pada nilai mata kuliah lain membuat mayoritas mahasiswa enggan mengikuti perkuliahan matematika komputasi. Keadaan ini sangat menyurutkan semangat dan minat mahasiswa untuk belajar bahasa pemrograman. Ketika semangat dan minat sudah tidak ada maka secara ototmatis hasilnyapun tidak ada. Sementara berbagai program yang ada di perkulahan matematika komputasi memiliki banyak manfaat terhadap materi mata kuliah lain atau aplikasinya di kehidupan sehari-hari khususnya program delphi, seperti pada mata kuliah: Matematika Diskrit, Aljabar Elementer, Aljabar Linear, Kalkulus, Pengantar Dasar Matematika, Metode Numerik, Teori Bilangan, Metode Statistika, Trigonomettri, dan Geometri. Maka dalam hal ini, untuk menarik minat mahassiswa untuk mau belajar dan menguasai bahasa pemrograman pihak jurusan harus mengaitkan antara matematika komputasi ini dengan mata kuliah yang lain seperti beberapa mata kuliah tersebut di atas agar ada yang mengikat mahasiswa untuk tidak mengikuti perkuliahan matematika komputasi yang sungguh berpengaruh dalam penguasaan konsep dan teori dari materi perkuliahan matematika yang lain.

3) Perlu adanya sentuhan/penyuluhan/ pencerahan dari jurusan untuk memotivasi mahasiswa untuk mengikuti perkuliahan matematika komputasi. Menanamkan motivasi merupakan hal yang tidak mudah. Karena kita harus menguasai psikologi seseorang. Dalam keadaan seperti ini pencerahan dari jurusan selaku penyelenggara sangat dibutuhkan karena pencerahan tersebut akan mampu membuka cakrawala berpikir mahasiswa tentang manfaat dari bahasa pemrograman. Dengan mengetahui manfaat tersebut maka bakat, minat, motif, dan perhatian akan bahasa pemrograman khususnya program delphi akan semakin meningkat.

b. Pihak Laboran

Pihak laboran yang terdiri dari unsur pembina dan asisten pembina merupakan penyelenggara inti dan langsung bertatap muka dengan mahasiswa/praktikan. Berpijak dari faktor-faktor yang mempengaruhi kesalahan penulisan algoritma pemrograman 
delphi di atas maka sebagai penyelenggara inti dalam perkuliahan matematika komputasi harus melakukan beberapa upaya sebagai berikut:

1) Tujuan pembelajaran (perkuliahan/ praktikum) perlu disampaikan. Di setiap pertemuan dalam pembuatan aplikasi program seorang pembina atau asisten pembina perlu menyampaikan tujuan pembelajaran minimal tujuan atau manfaat dari aplikasi yang dibuat. Karena penyampaian tujuan tersebut akan mampu melahirkan minat atau motivasi mahasiswa dalam belajar pembuatan aplikasi tersebut.

2) Pembina atau Asisten pembina harus profesional. Profesionalisme seorang pembina atau asisten pembina akan berimplikasi pada gaya mengajar dan gaya mengajar akan berimplikasi pada tingkat pemahaman mahasiswa dalam menangkap apa yang dia sampaikan. Ketika pembina atau asisten pembina memiliki tingkat profesionalisme yang tinggi maka secara otomatis output dari perkuliahan tersebut akan berkualitas tinggi pula. Salah satu upaya yang dilakukan oleh jurusan penddikan matematika dalam meningkatkan profesionalisme pembina dan asisten pembina dengan dilakukannya berbagai pelatihan tentang bahasa pemrograman.

3) Modul perlu dilakukan perbaikan, materi ditambah dan diperdalam. Kualitas isi petunjuk praktikum memiliki peran penting dalam menentukan output dari praktikum itu sendiri. Karena kualitas isi yang baik dan interaktif akan mampu menanamkan konsep-konsep bahasa pemrograman khususnya program Delphi kepada mahasiswa. Sehingga akan lahir ide-ide baru dalam mengembangkan konsep yang sudah ada. Tentu hal ini akan berpengaruh pada kualitas hasil praktikum terutama pada mahasiswa sendiri sebagai objek praktikum. Menurut hasil observasi dan interview tentang keadaan modul praktikum program delphi memang membutuhkan perbaikan, kemudian materi ditambah dan diperdalam. Karena dengan penambahan dan perdalam materi maka akan menambah wawasan mahasiswa sebagai programer program delphi sehingga kualitas perkuliahan matematika komputasi khususnya program delphi semakin meningkat.
4) Metode perkuliahan harus memakai sistem pengelompokkan. Metode kelompok (cooperative) merupakan metode yang sangat bagus dalam peningkatan kualitas hasil dari suatu pembelajaran. Menurut observasi, diperoleh bahwa sistem kelompok baik pada mahasiswa maupun asisten pembina sangat baik. Tidak seperti yang terjadi di beberapa praktikum tahun sebelumnya seorang asisten pembia harus melayani satu kelas atau 40 mahasiswa selama praktikum. Sehingga hasilnya tidak memuaskan karena kebanyakan praktikan/mahasiswa tidak mendapat arahan atau sugesti langsung dari asisten pembina. Maka dari itu, asisten pembina harus secara berkelompok dalam waktu yang bersamaan menangani praktikum agar kondisi laboratorium selama praktikum berlangsung dalam keadaan aman, lancar, dan sukses. Dengan demikian tingkat kesalahan penulisan algoritma pemrograman delphi bisa diatasi atau diminimalisir.

c. Pihak Mahasiswa

Pihak terakhir yang harus berperan dalam mengatasi tingkat kesalahan penulisan algoritma pemrograman delphi adalah mahasiswa/praktikan itu sendiri. Adapun upaya-upaya yang harus dilakukan adalah sebagai berikut:

1) Perlu adanya kesadaran dan kreatifitas berpikir pada diri mahasiswa untuk menciptakan sesuatu yang baru (aplikasi). Karya sendiri adalah suatu anugerah yang akan pernah bisa kita lupakan. Karena karya tersebut merupakan hasil reatifitas berpikr kita selama ini. Namun yang terlihat di kalangan mahasiswa jurusan pendidikan matematika kesadaran dan kreatifitas berpikir pada diri mahasiswa untuk menciptakan sesuatu yang baru (aplikasi) masih kurang atau hampir tidak ada. Tentu hal ini berakibat pada motivasi dan minat mahasiswa untuk berkarya. Seperti diketahui bersama bahwa semakin lama maka ilmu semakin berkembang sehingga dibutuhkan kreatifitas untuk berkarya dan jangan terlalu terpaku oleh buku panduan. Maka untuk mengatasi masalah ini perlu adanya kesadaran dan kreatifitas berpikir pada diri mahasiswa untuk menciptakan sesuatu yang baru (aplikasi) agar ilmu matematika selalu hidup dan berkembang khususnya di kalangan mahasiswa jurusan pendidikan matematika UIN Mataram. 
2) Adanya sikap iri ketika seseorang menemukan ide atau konsep baru. Menurut hasil interview kepada para asisten pembina diperoleh data bahwa kurangnya rasa iri dalam diri mahasiswa ketika seorang mahasiswa lain menemukan ide atau konsep baru. Misalnya, ada seorang mahasiswa berhasil membuat sebuah aplikasi program delphi yang berawal dari ide atau kreatifitas sendiri maka oleh mahasiswa lain itu sudah lebih dari cukup dan tidak perlu ada persaingan untuk menciptakan yang baru lagi. Sikap iri seperti ini tidak ada dalam diri mahasiswa jurusan pendidikan matematika UIN Mataram. Sehingga berpengaruh pada faktor lain yakni minimnya motivasi dan minat untuk belajar algoritma pemrograman yang akan berimplikasi pada kurangnya pemahaman tentang algoritma pemrograman dan ujungnya berpengaruh pada tingkat kesalahan penulisan algoritma pemrograman. Untuk menghindari hal seperti ini maka perlu adanya sikap iri ketika seseorang menemukan ide atau konsep baru sebagai motivator dalam menciptakan berbagai aplikasi matematika baru yang bermanfaat bagi orang banyak khususnya mahasiswa matematika lainnya.

\section{SIMPULAN DAN SARAN}

Berdasarkan penelitian yang telah dilakukan maka peneliti dapat menyimpulkan beberapa hal sebagai berikut:

1. Kesalahan penulisan algoritma pemrograman Delphi pada semester ganjil Jurusan Pendidikan Matematika UIN Mataram terdiri dari beberapa bentuk, yakni:

a. Tidak mendeklarasikan (mendefinisikan) variabel yang digunakan dalam rumus atau instruksi.

b. Kesalahan penulisan pada tanda baca, seperti tanda baca titik, koma, titik dua, titik koma, tanda kurung, dan sama dengan.

c. Kesalahan penulisan pada huruf khususnya pada konversi data.

d. Kesalahan dalam mengkhiri instruksi pemrograman.

2. Faktor-factor yang mempengaruhi kesalahan penulisan algoritma pemrograman Delphi pada semester ganjil Jurusan Pendidikan Matematika UIN Mataram terdiri dari dua faktor, yakni:

a. Faktor-faktor Internal, terdiri dari:

1) Kemampuan komputerisasi mahasiswa masih kurang.

2) Minimnya pemahaman terhadap algoritma pemrograman Delphi. Faktor ini disebabkan oleh beberapa hal seperti, jadwal perkuliahan matematika komputasi belum teratur dan efektif, sugesti kurang dan berbeda dari masingmasing asisten pembina terhadap praktikan, dan tidak ada rasa iri atau semangat untuk berkompetensi pada diri mahasiswa.

3) Mayoritas mahasiswa belum mengetahui tujuan pembelajaran program Delphi. Faktor ini disebabkan beberapa hal seperti, rendahnya tingkat kesadaran pentingnya belajar program Delphi yang merupakan aplikasi dari teori matematika, adanya asumsi bahwa matematika komputasi tidak termasuk mata kuliah, dan disebabkan kesibukan, seperti kegiatan berorganisasi atau aktivitas perkuliahan.

b. Faktor-faktor Eksternal, terdiri dari: rendahnya tingkat profesionalisme asisten pembina, sarana atau fasilitas kurang memadai (lengkap), dan mutu isi modul atau panduan praktikum masih kurang kompetensi.

\section{UCAPAN TERIMA KASIH}

Tim Peneliti mengucapkan terima kasih kepada Laboran yang telah banyak membantu selama praktikum dan Mahasiswa Jurusan Pendidikan Matematika UIN Mataram yang telah bersedia meluangkan waktunya mengikuti praktikum Delphi ini dengan baik.

\section{REFERENSI}

[1] Afifuddin dan Beni Ahmad S. (2009). Metodologi Penelitian Kualitatif. Bandung: Pustaka Setia.

[2] Amirul Hadi. (1998). Metodologi Penelitian Pendidikan. Bandung: Pustaka Setia.

[3] Antony Pranata. (2005). Algoritma dan Pemrograman. Yogyakarta : Graha Ilmu.

[4] Emzir. (2010). Metodologi Penelitian Kualitatif : Analisis Data. Jakarta: Rajawali Pers.

[5] Lexy J. Moleong. (2010). Metodologi Penelitian Kualitatif. Bandung: PT Remaja Rosdakarya.

[6] Rinaldi Munir. (2005). Matematika Diskrit Edisi Ketiga. Bandung: Informatika.

[7] Syaharuddin, Vera Mandailina, Yunita Septiana Anwar. (2015). Pengembangan Software Matematika SMP/MTs Berbasis Solutif Menggunakan Borland Delphi. Jurnal Beta, 8(2), 183-192

[8] Sugiyono. (2010). Metode Penelitian Kuantitatif, Kualitatif, dan R\&D. Bandung: Alfabeta. 